\title{
THE ASSEMBLING OF CONTEXTUAL TEACHING AND LEARNING (CTL) MODEL ASSISTED BY ORIGAMI PAPER MEDIA FOR INCREASING PLANE LEARNING RESULT IN THE FIFTH GRADE OF PRIMARY SCHOOL
}

\author{
Dyah Tri Wahyuningtyas $^{1, *}$, Nury Yuniasih ${ }^{2}$, Edy Bambang Irawan ${ }^{3}$, Susiswo 4 \\ 1,2,3,4 Universitas Negeri Malang
}

\begin{abstract}
The objective of this study was describing the application of CTL model assisted by origami media for increasing learning result of plane circumference in the fifth grade of primary school. It was a qualitative research by using Classroom Action Research (CAR) methodology. The subject research was 43 students in the fifth grade in Bunuwetan Pakis primary school. The steps are: (1) Introduction, (2) Material presentment step (constructivism, inquiry, questioning, learning community, modelling, reflecting, and authentic assessment), conclusion and (3) Closing. The scoring result of this study was $80 \%$ in the activity of the teacher in cycle I, it included good category. In cycle II was getting $96 \%$ and including excellent category. The activity of the students was getting $67,14 \%$ and including quite active category. Besides, in cycle II it got $92,86 \%$, involved very active category. The result study in cycle I was gotten from classical mastery $69,77 \%$ and the average score was 63,83 . The cycle II was $81,39 \%$ and the average score was 80,93 . Therefore, can be concluded that the assembling of CTL model assisted by origami could increase the learning result of the fifth grade in Bunuwetan Pakis Primary school.
\end{abstract}

Keywords:

CTL, origami, plane

\section{Introduction}

A good achievement in learning is a hope of a teacher and students, and to reach it must apply a good learning and teaching process. "Mathematics is part of basic science that grow rapidly in content or the application and able to increase a student's ability to thing critical, systematic, logical, creative and an effective collaborative" Department of National Education, 2004). Even tough, the real what happen is showing that up to now the mathematics result does not look satisfying yet. The experts conveyed that these fact caused by various factors. Suharta (2000) stated that "factors of learning adversity for students in learning mathematics inasmuch the characteristics of mathematics itself that the general concepts are abstract." Based on Hudoyono (2000) the other which caused the appearance of weakness in learning mathematics is "the habit that only apply lecture method in learning and the less of teacher's ability to present proper learning approach in class management for motivating students and involving them in learning process".

Involving the students in learning activities is caused the less of understanding what the students get from the teacher is showing that a knowledge can not directly move, but must be constructed or at least interpreted by themselves. Besides, students' ability is variative, can not be denied it happens also in the most of education world. It happens inasmuch the heterogeneous inputs. In mathematics learning a teacher should not emphasize on the theoretical objective only but also emphasize in learning process and teaching and learning result. Learning mathematics should through a process that bear in simple concept to a complex concept. Each concept in mathematics can be understood well if it is presented in concrete way at the first. Russeffendi (1992) conveyed that props are a tool for explaining or manifest mathematics concept in order material lesson can be understood easily.

Based on observation result in the fifth grade Bunuwetan Pakis primary school was known that mathematics learning was still using conventional learning. The impact was students getting bored easily 
and less of attention to the teacher. The learning still centered on teacher, and students accepted and memorizing material formula only. Mathematics learning which oriented to a teacher caused a student does not built his own knowledge from the beginning to the end of the learning process. The teacher was dominating in classroom activities and the atmosphere was extremely passive inasmuch there was no interaction between the teacher and the students except waiting till pointed by the teacher. Some problems which had been conveyed are caused by passive learning activities. The impact is some of the students' learning results do not reach Standard of Minimum Completeness (SMC) yet. Because in fact the students in the fifth grade only $30 \%$ of the total 43 students got score reach out the SMC and the others $70 \%$ were under SMC. By this reason can be told if the learning result of the fifth grade Bunuwetan Pakis primary school is not maximal yet.

By this condition, it needs a model and learning media which must be used for overcoming this problem. One of learning models that interact and make the students active is contextual learning. Nur Hadi said that CTL is learning concept which stimulates a teacher for linking between a material and a student's real world. Jonhson stated that CTL is learning process which aimed for helping students looking the meaning in academic material that they learned by linking academic subjects with their daily activities context. Based on these meaning can be concluded that CTL is learning concept that help teacher to link between material and real world situation of the student and emphasize student make a relation between their knowledge and the application in daily life. Contextual learning involve main seven components from productive learning namely: Constructivism, questioning, inquiry, learning community, modelling, reflecting and authentic assessment (Department of National Education, 2003:5).

Primary school age is kids which the range of age in 7 to 12 years old that in operational concrete level, it means primary school students have not thought formally therefore the used of concrete thing is important. By staring cognitive development characteristics primary school students then in this case the researchers more emphasize on the use of concrete learning media and can be manipulated by the students in measuring activity is origami media. Learning media is a tool that used for communicating and interacting between teacher and students in school learning process (Oemar Hamalik, 1986: 23). Learning media that used by the researchers on learning circumference plane measurement was origami paper media. The used of origami media was used for helping the fifth grade students in understanding measurement circumference of plane. Because based on Cai, et al (2005) we have to support the development thinking of the students start from fifth grade to help them appreciate the function algebra approach in solving various question or problem.

The use of this learning media is used to set out from concrete things to abstract things. Started by acting out situation then from a real situation is replaced by concrete props have the shape of piece of origami. Afterwards, this origami is drown thus more abstract by sublimation technic which can be measure and stated in mathematical sentence, therefore, from these process can be known the formula to looking for a circumference of plane. This media is composed from small pieces from colourful origami paper and cut by specific size then can be used for finding measurement concept on plane through sublimation way easily and appropriately. By assembling CTL learning model assisted by origami paper media was expected can increase mathematic learning result in circumference of plane material in the fifth grade students Bunuwetan Pakis primary school.

\section{Method}

Research methodology the use of origami paper media for increasing students' learning result in measurement circumference of plane was Classroom Action Research (CAR) with the 43 fifth grade students of Bunuwetan Pakis primary school as subject research. Classroom Action Research model that used in this study was classroom action research cycle model that developed by Kemmis and Mc. Taggart. The research steps involve: (1) determination of research focus is the researchers ask research permission, preliminary observation, giving pre-test to the students, validating the learning media and research instrument to validator, giving preliminary test, (2) planning was prepare and compile research instrument, (3) implementation of the action was implementing lesson plan by using origami paper and conduct the last test, (4) observation and interpretation are recording learning process of the students when the action was going and did an interview, (5) analysing and reflecting are analysing the students' understanding level based on the students' answer in the last test and assessing the students' average score, data describing from observation and interview result and reflecting what do not conduct yet and 
what need to be enhanced. This reflection result would be used for improvement in the next cycle. The form of research instrument that would be used in research is as follows: (1) question test, (2) observation sheet, (3) interview, (4) validation sheet.

After the data which consists of teacher's activity observation sheet, students' activity observation sheet, preliminary test and the last test result and interview result had been collected, the next process was conduct an analysis. Data analysis step which used in research consists of 3 steps namely: (1) data reduction was a procedure describing implementation in learning by using origami paper media, classifying understanding concept level in research through the students' test result, (2) presenting the data was constructing a graphic for knowing data distribution about the students' test result, (3) concluding and verifying the data is checking the success of research based on success criteria that had been set and verifying the students' mistake in understanding concept on test result in each part of question. Next, the researchers conducted verification or asking towards the students' who still did some mistake on the test about the mistake and the difficulties toward the test. In this research taking conclusion and verification were done toward the understanding concept result of the students when the test went. Then, the result of taking conclusion and verification would determine whether or not the researchers did the next cycle.

\section{Results And Discussion}

CTL learning model assisted by origami paper media in this research consisted of some steps, they were: (1) Introduction, the teacher started the learning process by repeating the previous material and explained learning steps,; (2) Explanation of material, in this step the teacher explained the material and the rules origami media; (3) Constructivism, the teacher explained the circumference of plane material by using origami media, then the teacher spreaded origami paper to the students and gave them a task making a plane corresponding by the material that had been explained by the teacher; (4) Inquiry, in this step the teacher provided guidance to students in order to find trapezoid circumference of plane concept by using origami paper media, then student representatives came forward to present the result of his task specifically trapezoid circumference of plane concept by using origami paper media to his friends; (5) Questioning, in questioning step the teacher gave a chance to the students for asking around material that did not understand yet; (6) Learning community, the teacher constructed some group contained 4 to 5 person for doing a discussion and question and answer section; (7) Modelling, the teacher distributed LKS for each group, and gave some instruction and example how to measure trapezoid circumference of plane by using origami paper media that the students did not have any difficulties when did the task; (8) reflecting, teacher and students did a reflection for activities which had been done specifically measuring trapezoid circumference of plane assisted by origami paper media; (9) authentic assessment, the teacher distributed evaluation question that have to be done by all of the students then gave an assessment; (10) Conclusion, the conclusion from learning that had been done.

Learning by CTL model assisted by origami media paper in line with Sanjaya (2017) media users are able to enhance learning motivation of the student that students' attention towards the material more increase. When learning process was taking place the students' result was more increasing from the firs and the second meeting. These show that there was an improvement of the students learning result; it can be seen from the teacher activity observation result, students activity observation result, and result of the last test. When the learning process by CTL model assisted by origami media paper was taking place the students were very active. Overall, the data of activity result in cycle I and II can be seen in this table:

Table 5.1 Percentage of Success Criteria

\begin{tabular}{lcc}
\hline \multicolumn{1}{c}{ Success Criteria } & Cycle I & Cycle II \\
\hline Material Understanding & & \\
The percentage of the students who reach the SMC & $63,83 \%$ & $81,39 \%$ \\
Learning liveliness & & \\
Liveliness Students' Percentage & $67,15 \%$ & $92,86 \%$ \\
Liveliness Teacher's Percentage & $80 \%$ & $96 \%$ \\
\hline
\end{tabular}

\section{Conculsion and Suggestion}

The assembling of CTL (Contextual Teaching and Learning) learning model assisted by origami paper media in circumference of plane material went very well. This is proven by the teacher activities in 
cycle I that categorized "good" with an average score $80 \%$ and in cycle II that categorized "very good" with an average score $96 \%$, there was an improvement of teacher activity. The steps of assembling CTL model were Introduction, Material presentment step (constructivism, inquiry, questioning, learning community, modelling, reflecting, and authentic assessment), conclusion and Closing. Based on those steps, the learning liveliness of the students was more increasing from the cycle I that categorized "quite active" with an average score $67,14 \%$ and cycle II that categorized "very active" with an average score $92,86 \%$.

The assembling of CTL learning model assisted by origami paper media in circumference of plane material on the cycle I there were 30 students completed the learning with the percentage of mastery $69,77 \%$, and the average score of the learning result was 68,83 . Besides, on the cycle II there were 35 students completed the learning with the percentage of mastery $81,39 \%$ and the average score of the learning result 81,39. Based on the analysis data result and the discussion at the previous chapter that it can be concluded if the mathematics result study in the fifth grade Bunuwetan Pakis primary school can be increased by the assambling of CTL learning model assisted by origami learning media. This is proven by the research result that shows the learning result reach the SMC 70 with students' mastery learning percentage result $\geq 80 \%$.

\section{Refferences}

Arikunto. 2007. Prosedur penelitian Suatu pendekatan Praktik. Jakarta: PT Rineka Cipta)

Attec. 2000. Analisa Data Kuantitatif. Bandung:Pustaka Ilmu

Bruner. 2000. Belajar penemuan . Bandung: Pustaka Setia

Cai dkk . 2005.Jagoan origami Dengan Prestasi Global. Jakarta :Pustaka Ilmu

Depdiknas. 2002. Perbedaan antara pembelajaran Contextual Teaching learning (CTL) dengan Pembelajaran Konvensional

Djaali. 2007. Psikologi pendidikan. Jakarta: Bumi Aksara

Elaine B.Johnson. 2011. Contextual Teaching And Learning. Bandung: Kaifa

Hadi, Nur. 2000. Konstektual dan penerapannya dalam KBK Malang : UM PRESS

Hudoyono. 2000 Pengembangan Kurikulum Dan Pembelajaran Matematika.

Jeromi Burner. 2001. Teori Belajar Mengajar. Jakarta: Bumi Aksara

Johnson. 2010. Contextual Teaching And Learning . Jakarta:Mizan learning Center (MLC)

Kemmis \& Mc.Tagart (1988)The Action Researcher Planner . Victoria: Deakin University

Kennedy L.M. \& Tips .1994 Guilding Children's of leraning of mathemathics Belmont. California: Wadsworth Publishing Company

Maman, Tisna. 1997. Media Pembelajaran. Jakarta :Erlangga

Oemar. 1980. Psikologi Belajar mengajar. Bandung :Sinar baru

Prabawanto (2010) Penelitian Tindakan Kelas/PTK. Bandung: Rosda karya

Riduwan. (2007) Rumus Data Dalam Aplikasi Statistika. Bandung: Alfabeta

Roestiyah (2010) StrategiBelajarMengajar, Jakarta: RinekaCipta

Rusffendi. (1984) Membantu Guru mengembangkan Kompetensinya dalam pengajaran. Bandung: Tarsito

Russffendi. 1992. Pensisikan Matematika. Jakarta: Dekdikbud)

S.Nasution. 1980. Berbagai Pendekatan Dalam Proses Belajar mengajar. Bandung: Bumi Aksara

Sanjaya, Wina (2007) Strategi Pembelajaran. Jakarta: Prenada media

Slavin. (2016) Cooperative learning:Teori ,Riset dan praktik. Jakarta:Nusa Media

Sudiman.1997. Media pembelajaran Dan Proses Belajar mengajar. Bandung:Bumi Aksara

Suharjono (2008) Penelitian tindakan Kelas. Jakarta:Bumi Aksara

Suharta. 2006. Pengembangan Kurikulum Dan Pembelajaran Matematika.

Yamin (2009) ManajemenPembelajarankelas, Bandung: Rosdakarya 